\title{
Grounded in a Human Science Paradigm: Human Caring to Overcome Challenges to Humanize Nursing Education
}

For nursing students, who enter educational programs primarily to care for others, uncaring encounters may be extremely detrimental for them as individuals. .. If nursing education programs do not fundamentally aspire to actualizing caring encounters, learning may be sabotaged, leading to inappropriate and/or a lack of understanding of the importance of caring as the foundation of nursing.

—Adams and Maykut, 2015, p. 768

\section{LEARNING INTENTIONS}

- Sensitize nurse educators about the impact of dehumanizing teaching practices on students and their learning.

- Reflect on how Human Caring can overcome dehumanizing teaching practices in order to humanize nursing education. 
- Appreciate how Human Caring can promote students' learning and foster their caring praxis.

- Understand, from students' perspective, how dehumanizing teaching practices can impede their learning and success.

\section{INTRODUCTION}

We first acknowledge a darker aspect of nursing education: nurse educators' dehumanizing practices toward students. After explaining this unfortunate, yet frequent, phenomenon and its impact on both the students and their learning, we discuss the importance of Human Caring in overcoming such challenges in order to humanize nursing education and ground the educator's role, and the teaching/learning relationships. We introduce the added value of caring relationships for students and nurse educators alike, and we present our philosophical foundation to support our Human Caring approach as a cornerstone to enhance humanization in nursing education. A Pragmatic Segment will illustrate these ideas more concretely.

\section{WHY WE NEED TO HUMANIZE NURSING EDUCATION}

Dehumanizing practices are no longer just studied or addressed in clinical nursing, but they are also prevalent in nursing education. In fact, there are some authors who are beginning to discuss dehumanizing practices in nursing education.

According to Haslam (2006), dehumanizing practices appear in academic domains mostly because of the prevalence of standardized assessment and teaching practices, "which are rigid and impersonal and treat students as passive and uncreative" (p. 254). Hills and Cara (2019) explain that the traditional behaviorist paradigm, which considers nurse educators as the experts teaching the only desirable behaviors to be evaluated, may contribute to such educational practices. Indeed, this behaviorist perspective fails to recognize the uniqueness and diversity of students and their learning processes; does not consider an interactive and heuristic approach to students' learning; and, most importantly, does not acknowledge the importance of the student-educator relationship in their learning.

In nursing education literature, such dehumanization is given different labels, including uncaring behaviors, unethical attitudes, incivility, bullying, abuse, harassment, as well as horizontal and lateral violence (see Table 1.1). In this book, we use the term debumanizing teaching practices. 
Table 1.1 Different Concepts or Constructs Used in the Nursing Literature

\begin{tabular}{|c|c|}
\hline Constructs Used & Authors \\
\hline Uncaring behaviors & Cara and Hills (2018) \\
\hline Uncaring encounters & Halldorsdottir (1990) \\
\hline Incivility & $\begin{array}{l}\text { Beck (2015); Muliira, Natarajan, and van } \\
\text { der Colff (2017); Ziefle (2018) }\end{array}$ \\
\hline Bullying & $\begin{array}{l}\text { Adams and Maykut (2015); Birks, } \\
\text { Budden, Stewart, and Chapman (2014); } \\
\text { Seibel and Fehr (2018); Stagg, Sheridan, } \\
\text { Jones, and Speroni (2013) }\end{array}$ \\
\hline Abuse & Stagg et al. (2013) \\
\hline Harassment & Birks et al. (2014) \\
\hline Horizontal and lateral violence & $\begin{array}{l}\text { Hills and Watson (2011); Seibel and Fehr } \\
\text { (2018); Thomas (2010) }\end{array}$ \\
\hline Unethical attitudes & Arslan and Dinç (2017) \\
\hline
\end{tabular}

Although contemporary literature addresses reciprocal dehumanizing practices (both nurse educators toward students and students toward nurse educators), in this book, we concentrate on nurse educators' dehumanizing teaching practices toward students. An example of such dehumanizing practices in nursing education could be a nurse educator humiliating his or her students in front of classmates in the classroom or in front of patients, family members, nurses, physicians, or other healthcare professionals during their clinical practicum.

\section{Dehumanization: Understanding the Phenomenon}

Dehumanization, in general, has been discussed mostly in relation to healthcare and organizations. According to Christoff (2014) and Haslam (2006) who are both from the field of psychology, "dehumanization" is defined as the fact that a person is being objectified or considered as an object. Moreover, it often occurs with indifference, a lack of empathy, along with an abstract and stigmatized view of the person (Haslam, 2006). In their study with rehabilitation patients, dehumanization has also been associated with work overload, bureaucracy, lack of time, and a task-oriented approach (Avoine, 2012; Avoine, O'Reilly, \& Michaud, 2012; Avoine, O’Reilly, Michaud, \& St-Cyr Tribble, 2011). 
Considering more closely the expression "uncaring encounters," Halldorsdottir's work $(1990,1991,2013)$ can be extremely valuable to understand dehumanization, dehumanizing practices, as well as their damaging impacts on the person. She describes "uncaring encounters" as corresponding especially to three modes of being with another. She refers to the first one, the "life-destroying (biocidic) mode of being with another" (see Table 1.2), as the most inhumane encounter (Halldorsdottir, 2013, p. 202). This is a "mode where one depersonalizes the other, destroys the joy of life, and increases the other's vulnerability. It causes distress, despair and hurts and deforms the other. It is transference of negative energy and darkness" (Halldorsdottir, 2013, p. 202). This author explains that this particular uncaring encounter mode is characterized by numerous manifestations of inhumane attitudes by the nurse, for example, aggression, manipulation, humiliation, dominance, coercion, and depersonalization. According to Halldorsdottir, the person's reaction can range from puzzlement and disbelief, to anger and resentment, to helplessness and despair. For example, in nursing education, an educator could humiliate a student in front of her or his colleagues for failing an assignment.

Halldorsdottir (2013) explains the second mode, the "life-restraining (biostatic) mode of being with another" (see Table 1.2), as a "mode where one is insensitive or indifferent to the other and detached from the true center of the other. It causes discouragement and develops uneasiness in the other. It negatively affects existing life in the other" (p. 202). According to this author, this second type of uncaring encounter entails forcing one's own will and dominating and controlling the other person. Moreover, during such an uncaring encounter, Halldorsdottir (2013) describes that the nurse's presence is considered as disruptive as exhibiting rudeness and lack of kindness. For example, in nursing education, in wanting to display better knowledge of the course and its contents, sometimes nurse educators could show a bitter response and discourage or even fail a student simply for having a different point of view than theirs.

Halldorsdottir (2013) explicates that the third mode, "life-neutral, or biopassive, mode of being with another" (see Table 1.2), takes place "when one is detached from the true center of the other and when there is no effect on the energy or life of the other. This lack of response, interest, and affect derives from inattentiveness or insensitivity" (p. 205). Although there is no tangible effect on the person's life, Halldorsdottir argues that such uncaring encounters may often create a feeling of loneliness from the absence of relationships. For example, in nursing education, educators could be insensitive to their students' difficulties in the classroom and may not want to connect and accompany them to foster their learning.

Dehumanization corresponds to the fact of being treated as an object with an obvious lack of respect. It also implies being deprived of one's own 


\section{Table 1.2 Dehumanization From Halldorsdottir's Mode of Being} With Another

\begin{tabular}{|c|c|c|}
\hline $\begin{array}{l}\text { Halldorsdottir's Mode } \\
\text { of Being With Another }\end{array}$ & Nurses' Attitudes & $\begin{array}{l}\text { Consequences } \\
\text { for the Person }\end{array}$ \\
\hline Life-destroying (biocidic) & $\begin{array}{l}\text { Aggression } \\
\text { Manipulation } \\
\text { Humiliation } \\
\text { Domination } \\
\text { Coercion } \\
\text { Depersonalization }\end{array}$ & $\begin{array}{l}\text { Vulnerability } \\
\text { Suffering } \\
\text { Distress } \\
\text { Despair } \\
\text { Anger } \\
\text { Resentment } \\
\text { Helplessness }\end{array}$ \\
\hline Life-restraining (biostatic) & $\begin{array}{l}\text { Insensitivity } \\
\text { Indifference } \\
\text { Disruptive } \\
\text { Controlling } \\
\text { Rudeness }\end{array}$ & $\begin{array}{l}\text { Affecting negatively } \\
\text { Discouragement } \\
\text { Uneasiness }\end{array}$ \\
\hline Life-neutral (biopassive) & $\begin{array}{l}\text { Lack of response } \\
\text { Lack of interest } \\
\text { Inattentiveness } \\
\text { Insensitivity }\end{array}$ & $\begin{array}{l}\text { Loneliness from } \\
\text { the absence of } \\
\text { relationships }\end{array}$ \\
\hline
\end{tabular}

Source: Adapted from Halldorsdottir, S. (2013). Five basic modes of being with another. In M. C. Smith, M. C. Turkel, \& Z. R. Wolf (Eds.), Caring in nursing classics. An essential resource (pp. 201-210). New York, NY: Springer Publishing Company.

human dignity and personhood—no longer being acknowledged as a human being-which may amplify one's frustrations, vulnerability, suffering, and despair.

Several authors have identified various nurse educators' dehumanizing practices, such as:

- Exhibiting rigidity

- Rudeness

- Disparaging feedback

- Avoidance

- Unethical action

- Racism

- Condescension

- Favoritism

- Discrimination

- Objectification (Adams \& Maykut, 2015; Arslan \& Dinç, 2017; Beck, 2015; Cara \& Hills, 2018; Muliira, Natarajan, \& van der Colff, 2017; Seibel \& Fehr, 2018; Ziefle, 2018). 
According to Christoff (2014), there are various levels of dehumanization, ranging anywhere from mild and subtle (e.g., subtle disrespect and condescension) to obvious and severe (e.g., neglect and social ostracism).

As Arslan and Dinç (2017) explain,

the teacher-student relationship is inherently one of power, based on teachers' professional knowledge, skills, and authority and students' dependence. Power and position asymmetry within this relationship creates the potential for the mistreatment, abuse and exploitation of students, negatively influencing students' formal socialization and the effectiveness of education. (p. 790)

These nurse educators' dehumanizing practices may generate various emotions in students such as anxiety, stress, and powerlessness (see Table 1.3). Christoff (2014) explains that dehumanization, in general, can leave a person feeling angry, degraded, incompetent, excluded, and not recognized as a human being.

Table 1.3 Examples of Students' Responses to Nurse Educators' Dehumanizing Practices and Their Impacts

\begin{tabular}{|c|c|}
\hline Students' Responses & Impacts \\
\hline Anxiety & Decreased learning \\
\hline Stress & Depression \\
\hline Humiliation & Suffering \\
\hline Powerlessness & Attrition \\
\hline Distress & Failure \\
\hline
\end{tabular}

Sources: Data from Adams, L. Y., \& Maykut, C. (2015). Bullying: The antithesis of caring acknowledging the dark side of the nursing profession. International Journal for Caring Sciences, 8(3), 765-773. Retrieved from http:// www.internationaljournalofcaringsciences.org/docs/28_Adams_special_8_3.pdf; Arslan, S., \& Dinç, L. (2017). Nursing students' perceptions of faculty members' ethical/unethical attitudes. Nursing Ethics, 24(7), 789-801. doi:10.1177/0969733015625366; Beck, D. M. (2015). Incivility and student and faculty relationships: Implications for revising mentorship programs for nurse educators. SOJ Nursing \& Health Care, 1(1), 1-10. doi:10.15226/2471 6529/1/1/00103; Cara, C., \& Hills, M. (2018, May). The added value of Caring Science: Its contributions to humanize nursing education. Oral presentation, Canadian Association of Schools in Nursing (CASN) Conference, Montreal, QC, Canada; Muliira, J. K., Natarajan, J., \& van der Colff, J. (2017). Nursing faculty academic incivility: Perceptions of nursing students and faculty. BMC Medical Education, 17(1), 1-10. doi:10.1186/s12909-0171096-8; Seibel, L. M., \& Fehr, F. C. (2018). "They can crush you": Nursing students' experiences of bullying and the role of faculty. Journal of Nursing Education and Practice, 8(6), 66-76. doi:10.5430/inep.v8n6p66; Ziefle, K. (2018). Incivility in nursing education: Generational differences. Teaching and Learning in Nursing, 13(1), 27-30. doi:10.1016/j.teln.2017.09.004. 
Numerous authors have highlighted different impacts or consequences of dehumanizing practices for students, such as decreased learning, suffering, and failure (see Table 1.3). In fact, according to Seibel and Fehr (2018), "unaddressed bullying can lead to deeper issues such as entrenched negative behaviour. ... Students and new graduates leave the profession due to bullying" (p. 70).

Such impacts should be a huge concern for nurse educators. To quote Adams and Maykut (2015),

uncaring encounters occur ... speaking about the dark side is necessary; we can no longer pretend it doesn't exist or is inconsequential.... Addressing bullying, as an uncaring encounter, will ensure that as nurses we are able to accomplish the mandate of caring and protecting our patients. (p. 771)

\section{TIME OUT FOR REFLECTION}

The authors invite you to write your reflection in a journal in order to link the preceding theoretical segment with your personal teaching/ learning experiences.

Think about a time when you were in a situation where it felt dehumanizing, and then ask yourself the following questions:

- Who was involved?

- What were the characteristics illustrating dehumanization?

- What was your lived experience?

- How did you feel?

- What were you telling yourself at the time?

- What were the impacts at a personal level?

- What were the impacts for your teaching/learning practices?

- What solutions did you consider at the time to rehumanize the situation?

- Could it have been different? Explain briefly.

\section{HUMANIZING NURSING EDUCATION}

One way to shift from dehumanizing to humanizing nursing education is by adopting a humanist perspective. In general, such a perspective places emphasis on people, their experiences, their meanings, and their relationships (Cara, 2017; Cara \& Hills, 2018). In a nursing education context, a 
humanist perspective would, therefore, focus on the students, their learning experiences, their meanings, and their relationships (Cara \& Hills, 2018).

Humanist philosophers, such as Buber (1970/1996), Rogers (1961), and Mayeroff (1971/1990), have several beliefs in common. They

all considered humans' growth as a central component of their work. In fact, they clearly stated that human development is enhanced through a relationship, nurtured by both persons involved. These authors also shared a similar belief about authenticity (or congruence), understood as a quality of the relationship and as a prerequisite for its establishment. (Létourneau, Cara, \& Goudreau, 2017, p. 34)

In fact, these humanist philosophers have served as an underpinning for several caring theories in nursing, such as those of Watson (1985/1988, 2008, 2012), Roach (1984, 2002), Boykin and Schoenhofer (1993, 1993/2001), as well as Cara et al. (2016), mainly because of their emphasis on concepts such as "relationship" and "growth." Furthermore, a humanist perspective is grounded in humanistic values, such as respect and human dignity, suggesting that nurse educators should rethink the importance of preserving their students' human dignity when dealing, for example, with learning difficulties and failures (see also Chapter 2, Educators' Caring Values, Attitudes, and Behaviors That Contribute to the Humanization of Nursing Education).

Therefore, Human Caring could contribute to rehumanize nursing education by inviting nurse educators to focus on their relationships with students and nurture students' professional growth, by accompanying them to become the best nurses possible.

\section{Human Caring in Nursing Education}

"Caring Science provides this deep underpinning for a scientific-philosophicalmoral context from which to explore, describe, and research human caringhealing phenomena ... that informs and inspires the discipline and profession of nursing" (Hills \& Watson, 2011, p. 12). In other words, Human Caring provides a disciplinary foundation comprising science, ontology, and ethics to guide nurse educators to humanize nursing education. By "ontology," we mean the nature of being, our existence, as well as the reality. Hence, as many have suggested (Bevis \& Watson, 1989/2000; Boykin, Touhy, \& Smith, 2011; Hills \& Watson, 2011), nursing education programs would gain from being based on a clear moral, theoretical, and philosophical foundation, such as Human Caring. Such a perspective would then inform teachers on how to become a caring nurse educator, being one's moral imperative. 
We can then ask the question, What does it mean to be/become a caring nurse educator? To be/become a caring nurse educator is to develop humanist relationships with students in order to promote their learning, their personal meaning, and their dignity (Cara \& Hills, 2018). Developing a caring pedagogical relationship requires interactions between the nurse educators and their student(s) that are respectful, authentic, humanist, and are based on equity, trust, and safety (see Chapter 5, Seeking Teaching/Learning Caring Relationships With Students). Consequently, the student-educator relationship is fundamental, but a caring nurse educator's main goal is not solely the relationship in itself, but rather primarily, the students' learning. Indeed, a nurse educator, inspired by a Human Caring approach, will accompany students in their learning of what nursing is and ought to be, in order for them to find their learning meaningful.

Several authors have acknowledged the importance of student-educator relationships in students' learning (Boykin, Touhy, \& Smith, 2011; Cara et al., 2016; Cara \& Hills, 2018; Chan, Tong, \& Henderson, 2017; Froneman, Du Plessis, \& Koen, 2016; Hills \& Cara, 2019; Hills \& Watson, 2011; Labrague, McEnroe-Petitte, Papathanasiou, Edet, \& Arulappan, 2015; Noddings, 2013; Smith \& Crowe, 2017; Whealan, 2017). "One of the most important factors influencing education quality and effectiveness is teacher-student interaction" (Arslan \& Dinç, 2017, p. 790). In other words, student-educator relationships are ontologically fundamental to students' learning. Nurse educators' caring ontology, acknowledging the relational aspect of teaching as central for students' learning, will guide them to being and becoming caring educators.

\section{Added Value for Students and Nurse Educators}

Whealan (2017) acknowledges the importance of caring in nursing education. "From an educator's perspective, helping students develop caring literacy is a moral imperative because caring is the very essence of nursing. How we, as educators, instill and nurture caring among students is vital" (p. 40).

Several authors and researchers have highlighted the added value of the student-educator relationship for students-decreased anxiety, feeling more confident and resilient, feeling empowered, and so forth (see Table 1.4). Several authors have also recognized the overall contribution to students' general learning to improve their caring practices for their patients in clinical settings (see Table 1.4).

In contrast, only a few authors and researchers have highlighted the added value of the student-educator relationship for nurse educators (see Table 1.5). 
Table 1.4 Added Values of Student-Educator Relationships for Students

\begin{tabular}{|c|c|}
\hline Added Values for Students & Authors \\
\hline Decreased anxiety & Chan, Tong, and Henderson (2017) \\
\hline Feeling respected & $\begin{array}{l}\text { Beck (2001); Chan et al. (2017); Gillespie } \\
\text { (2005); Halldorsdottir (1990); Miller, } \\
\text { Harber, and Byrne (1990) }\end{array}$ \\
\hline $\begin{array}{l}\text { Feeling more confident and } \\
\text { resilient }\end{array}$ & $\begin{array}{l}\text { Beck (2001); Froneman, Du Plessis, } \\
\text { and Koen (2016); Labrague, McEnroe- } \\
\text { Petitte, Papathanasiou, Edet, and } \\
\text { Arulappan (2015) }\end{array}$ \\
\hline Feeling empowered & $\begin{array}{l}\text { Beck (2001); Hills and Watson (2011); } \\
\text { Miller et al. (1990) }\end{array}$ \\
\hline Growth and transformation & $\begin{array}{l}\text { Beck (2001); Gillespie (2005); } \\
\text { Halldorsdottir (1990); Hills and Watson } \\
\text { (2011); Miller et al. (1990) }\end{array}$ \\
\hline Increased general learning & $\begin{array}{l}\text { Beck (2001); Cara et al. (2016); Chan } \\
\text { et al. (2017); Froneman et al. (2016); } \\
\text { Gillespie (2005); Halldorsdottir (1990); } \\
\text { Hills and Watson (2011); Labrague et al. } \\
(2015)\end{array}$ \\
\hline $\begin{array}{l}\text { Improved clinical caring } \\
\text { practices }\end{array}$ & $\begin{array}{l}\text { Beck (2001); Cara et al. (2016); Chan } \\
\text { et al. (2017); Froneman et al. (2016); } \\
\text { Gillespie (2005); Halldorsdottir (1990); } \\
\text { Hills and Watson (2011); Labrague et al. } \\
\text { (2015) }\end{array}$ \\
\hline
\end{tabular}

Table 1.5 Added Values of Student-Educator Relationships for Nurse Educators

\section{Added Values for Nurse Educators Authors}

\begin{tabular}{|l|l|}
\hline Hope for the future of nursing & Miller, Haber, and Byrne (1990) \\
\hline Holistic concerns for their students & Beck (2001); Miller et al. (1990) \\
\hline Enthusiasm for teaching & Chan, Tong, and Henderson (2017) \\
\hline Professional growth & Gillespie (2005); Miller et al. (1990) \\
\hline Well-being & $\begin{array}{l}\text { Froneman, Du Plessis, and Koen } \\
(2016)\end{array}$ \\
\hline $\begin{array}{l}\text { Overall quality of the education } \\
\text { offered }\end{array}$ & Froneman et al. (2016) \\
\hline
\end{tabular}




\section{TIME OUT FOR REFLECTION}

The authors invite you to write your reflection in a journal in order to link the preceding theoretical segment with your personal teaching/ learning experiences.

Think about a time when you were in a situation where it felt humanizing for yourself and your student. Again, ask yourself these questions:

- Who was involved?

- What were the characteristics reflecting the humanization?

- What was your lived experience like?

- How did you feel?

- What were you telling yourself at the time?

- What were the advantages for your student?

- What were the advantages for yourself and in your teaching/learning practices?

\section{HUMAN CARING WITHIN A HUMAN SCIENCE PARADIGM}

Historically, most nursing programs have been based in an orthodox, positivistic, and behavioral paradigm (Bevis \& Watson, 1989/2000; Hills \& Watson, 2011; National League for Nursing [NLN], 1988, 2003) or, as Zander and Zander (2002) label it, a "world of measurement." This worldview has an ontology of separation and compartmentalization. It attempts to be neutral but actually values objectivity and is reductionistic. This empiricist worldview uses an objectivist-empirical epistemology to understand the world through probability statistics and suggests that everything can and must be measured (Hills \& Watson, 2011). It embraces an experimental methodology typically using large datasets and scientifically controlled procedures. As Reason (1994) explains,

orthodox research methods, as part of their rationale, exclude human subjects from all the thinking and decision-making that generates and designs, manages and draws conclusions, from the research. Such exclusions treat the subjects as less than self-determining persons, alienate them from the inquiry process and from the knowledge that is its outcome, and thus invalidates any claim the methods have to a science of persons. (p. 280) 
By contrast, Human Caring is situated in a Human Science paradigm, which has a relational ontology that values subjectivity and peoples' experiences (Hills \& Watson, 2011; Watson, 2012). This Human Science paradigm values multiple ways of knowing and knowledge and uses an expanded pluralistic epistemology to understand the world. It seeks understanding of meaning and peoples' experiences using multiple methodologies such as narrative inquiry, phenomenology, ethnography, and artistic methods.

Locating nursing education in this Human Science paradigm requires a shift in thinking, being, and doing that holds people and our humanity at the center of our educational practice. This means what educators say and do and the way that they are ("their being") is paramount in every interaction and transaction with their students. It lays the

foundation for reconnecting the heart, soul, mind, emotions, and the human spirit of students and teachers alike; it invites passion, intellect, moral ideals, and love into our classrooms and curriculum, restoring humanity and human caring-healing knowledge and practices for now and the future. (Hills \& Watson, 2011, p. 16)

\section{PRAGMATIC SEGMENT \\ HINDRANCE TO THE APPRENTICESHIP \\ OF HUMANISTIC CARING BY NURSE EDUCATORS: THE INFLUENCE OF NURSE EDUCATORS' LACK OF HUMANISTIC CARING ON STUDENTS' LEARNING}

\section{Dimitri Létourneau, PhD, RN}

First and foremost, it is our belief that no educator makes the conscious choice of being "dehumanistic" toward students: It is rather a "sly and insidious" process, as described by Avoine (2012). Moreover, in agreement with Booth, Emerson, Hackney, and Souter (2016), we believe that clinical nursing and nursing education are two distinct disciplines and a "great nurse" is not necessarily a "great educator." However, as Roberts and Glod (2013) explained, some educators in the academic field may have less interest in education than they do in research activities. As a consequence, committing to students' success beyond what is generally required (i.e., the "extra steps") may seem less appealing for tenure purposes. If an educator does 
not have genuine motivation and interest in being a caring educator, chances are that it will be visible in attitudes and behaviors. As stated earlier in this book and as Mayeroff (1971/1990) pointed out, Human Caring must be genuine; otherwise, it becomes a noncaring obligation. It may, in other words, be perceived as "fake," and it may impair both the students' and the educators' commitment to cocreate a caring relationship.

In a phenomenological study conducted by Létourneau, Goudreau, and Cara (2018) aiming at understanding the experience of learning to care for the person with humanism, from the perspectives of nursing students $(n=18)$ and nurses $(n=8)$, results shed some light on educators' dehumanizing practices and their potential impacts on learning. Those practices had many forms, some being the educators' spoken words and others being attitudes or behaviors.

\section{Insufficient Acknowledgment of Students' Feelings and of Challenges in Their Learning}

When it comes to spoken words, the results show that the "way" things are said is sometimes more brutal than the content itself. For instance, one second-year student, who we will call Hallay, recalled an experience where she perceived harshness in the educator's response. In short, this educator wanted to explain to students, who previously shared their concerns about workload and academic results, that assessment was based on their assignments' performances and not on the efforts put into them. Nevertheless, Hallay stated that this educator told students "she wasn't there to assess efforts [they] put into [their] work," which appears to be true, but was also perceived as devoid of empathy in regard to their formerly shared concerns. If this educator had started by acknowledging and mentioning how hard it could have been for students to complete their assignment, hopefully this experience would not have been remembered as "negative" as it was. Furthermore, if this educator had softened the way she explained how assessment was preferred in this course (i.e., not based on efforts) and showed openness and flexibility by asking students what their solutions to their concerns would have been, then again students could have perceived that their concerns were really listened to. Hallay and other participants mentioned that they felt an incongruence between what they were asked to become (i.e., caring practitioners) with the way they were "treated" as students. These participants identified 
such incongruence as limiting their learning and feeding their cynicism. This cynicism consequently appeared to impede their interest in endorsing Human Caring for their future practice.

\section{Lack of Interest in Students' Success and Learning}

As for attitudes and behaviors, Shélanie, a third-year student, in her own words spoke about what Halldorsdottir $(1991,2013)$ calls the "lifeneutral (biopassive) mode of being." Shélanie revealed that one of her educators, in contrast to others, did not appear interested in students' learning nor success. Instead, this educator was viewed as "someone who was giving assignments" rather than someone who embodied Human Caring in their way of being as a person. While this educator was not necessarily at the end of the "humanistic-dehumanistic" spectrum, it does look as if their attitudes did not make students feel that the educator was committed to helping the students become caring and humanistic nurses. Other participants encountered educators whose attitudes were described as "cold," "insensitive," or "detached" and this is closer to the "life-restraining (biostatic) mode of being" in Halldorsdottir's theory $(1991,2013)$. Because of these uncaring attitudes, Shélanie and other participants considered themselves less interested in acquiring knowledge from these educators: their passion for learning receded and their involvement in their courses declined.

\section{Marked Hierarchical and Haughty Approach With Students}

Some educators' approaches were perceived as hierarchical and haughty with students. Catherine, a second-year student, had clear memories of one faculty lecturer who made her, and her colleagues, feel belittled. In Catherine's own words, this faculty lecturer had a "superior look" on their face and seemed to be engaged in nursing education for reasons of prestige rather than for "good ones" (i.e., supporting students' learning). Catherine did not feel disrespected by this faculty lecturer; however, she did not believe that she could maintain a close student-educator relationship either. Additionally, she believed that this lecturer's approach was not congruent with Human Caring nor with humanism, which led Catherine to feel a greater distance between herself and the educator. As Catherine later added, "you appreciate that the people telling you to be humanistic embody humanism themselves," echoing Hallay's perceived incongruence. 


\section{Devaluation of Human Caring in the Clinical Setting}

Clinical training is an area of nursing education that might be a little harder to inspire when it comes to caring practices. Even where a school's curriculum is to be grounded in Human Caring in agreement with Hills and Watson (2011), nurse preceptors (or clinical educators) in clinical settings might not believe in and encourage caring practices when accompanying students from said school. Indeed, we invite educators to remind themselves that despite all efforts put inside universities to promote a nursing practice anchored on Human Caring, clinical settings are imbued with a realistic aspect that is salient to students; hence, they represent what Duchscher (2001) called the "real world of nursing." That makes clinical training all the more important when it comes to ensuring humanistic approaches. Sadly, however, all too often, some nurse preceptors might undermine or undervalue Human Caring, sometimes implicitly and, at other times, explicitly. Shélanie later reflected on another lived experience where she felt that her nurse preceptor did not encourage nor view caring as a fundamental aspect of nursing. As Shélanie was trying to get to know her patient and when she later came back to her nurse preceptor to explain what she had learned from that patient, her nurse preceptor seemed uninterested and solely focused on medication to be soon administered. Shélanie added, "it was rather seen as a waste of time." Because nurse preceptors are responsible for students' assessment in their clinical training, giving rise to a power relationship as explained earlier in this chapter, certain students might make the choice of following what is asked by their nurse preceptor in order to obtain good grades, even though they are aware of an incongruence between what they are doing and what they wish to do (i.e., embody Human Caring). Not only does this prevent students from practicing and living caring in the moment, but it reinforces this idea of "theory-practice gap" between academic and clinical fields. For this reason, it is our belief that nurse educators also have the responsibility to inspire Human Caring in nurse preceptors.

The results from this phenomenological study appear to demonstrate that not only the theoretical content of Human Caring is important to students' learning but that it must be embodied by nurse educators in order to foster a caring praxis. We understand that not every faculty member might be passionate about nursing education, but we want to insist on their pivotal role in students' learning. As Catherine, a second-year student, recommended, 
it is to be humanistic to show [them] also how to be humanistic. In fact, everyone with everyone: the teachers, the tutors towards the students. It must be reciprocal, if the tutors and the professors display humanism, it might be easier for [them] to be humanistic because they are [their] role models after all. It's harder to manage, but nurse preceptors, without asking them to be "Godlike" humanists, but to encourage humanism. If it is espoused in the way of teaching, well it may be easier for [them] afterwards.

\section{CONCLUSION}

This chapter intended to raise nurse educators' consciousness about a darker aspect of nursing education: educators' dehumanizing practices toward students. After understanding this phenomenon and its impact on students and their learning, we discussed the importance of Human Caring to overcome the challenges in order to humanize nursing education, especially surrounding the student-educator relationships.

We have come to realize that, unfortunately, we are witnessing dehumanization in nursing education. Such dehumanization may have serious impacts on our students as well as their learning the profession. Létourneau's Pragmatic Segment exemplifies these impacts clearly. Moreover, Birks et al. (2014) argue that ineffectively controlling bullying problems in academia will have serious consequences for students as well as the nursing profession. How could we, as nurse educators, conquer these challenges and promote humanization in nursing education? We could teach with loving-kindness, act as role models for students, and promote a caring teaching/learning environment where students can feel safe to learn (Cara \& Hills, 2018). We strongly believe that Human Caring will make a difference in our students' learning and lives, as it is our foremost responsibility.

The teacher's role is to nurture the learner: to nurture the ethical ideal, to nurture the caring role, to nurture the creative drive, to nurture curiosity and the search for satisfying ideas, to nurture assertiveness and the spirit of inquiry together with the desire to seek dialogue about care, and to be available for that dialogue. The teacher's role is to interact with students as persons of worth, dignity, intelligence, and high scholarly standards. (Bevis, 2000, p. 174) 


\section{REFERENCES}

Adams, L. Y., \& Maykut, C. (2015). Bullying: The antithesis of caring acknowledging the dark side of the nursing profession. International fournal for Caring Sciences, 8(3), 765-773. Retrieved from http://www.internationaljournalofcaringsciences .org/docs/28_Adams_special_8_3.pdf

Arslan, S., \& Dinç, L. (2017). Nursing students' perceptions of faculty members' ethical/ unethical attitudes. Nursing Ethics, 24(7), 789-801. doi:10.1177/0969733015625366

Avoine, M.-P. (2012). La signification de pratiques déshumanisantes telles que vécues par des patients hospitalisés ou ayant été hospitalisés en centre de réadaptation (Master's thesis). Retrieved from ProQuest Dissertations \& Theses. (UMI No. MR96229).

Avoine, M.-P., O’Reilly, L., \& Michaud, C. (2012, May). The signification of debumanizing practices of nurses in a physical rehabilitation setting from the patient perspective: A phenomenological study. Oral presentation at the 33rd Annual Conference, International Association for Human Caring, Philadelphia, PA.

Avoine, M.-P., O'Reilly, L., Michaud, C., \& St-Cyr Tribble, D. (2011). Dehumanization in health care: A concept analysis. International fournal for Human Caring, 15(3), 60. doi:10.20467/1091-5710.15.3.59

Beck, C. T. (2001). Caring within nursing education: A metasynthesis. Fournal of Nursing Education, 40(3), 101-109. doi:10.3928/0148-4834-20010301-04

Beck, D. M. (2015). Incivility and student and faculty relationships: Implications for revising mentorship programs for nurse educators. SOf Nursing \& Health Care, 1(1), 1-10. doi:10.15226/2471-6529/1/1/00103

Bevis, E. O. (2000). Teaching and learning: The key to education and professionalism. In E. O. Bevis \& J. Watson (Eds.), Toward a caring curriculum: A new pedagogy for nursing (pp. 153-188). New York, NY: National League for Nursing.

Bevis, E. O., \& Watson, J. (2000). Toward a caring curriculum: A new pedagogy for nursing. New York, NY: National League for Nursing. (Original work published 1989)

Birks, M., Budden, L. M., Stewart, L., \& Chapman, Y. (2014). Editorial. Turning the tables: The growth of upward bullying in nursing academia. Fournal of Advanced Nursing, 70(8), 1685-1687. doi:10.1179/pma.2014.48.1.001

Booth, T. L., Emerson, C. J., Hackney, M. G., \& Souter, S. (2016). Preparation of academic nurse educators. Nurse Education in Practice, 19, 54-57. doi:10.1016/j .nepr.2016.04.006

Boykin, A., \& Schoenhofer, S. O. (1993). Nursing as caring: A model for transforming practice. New York, NY: National League for Nursing.

Boykin, A., \& Schoenhofer, S. O. (2001). Nursing as caring: A model for transforming practice. Sudbury, MA: Jones \& Bartlett Publishers \& National League for Nursing. (Original work published 1993)

Boykin, A., Touhy, T.A., \& Smith, M. C. (2011). Evolution of a caring-based college of nursing. In M. Hills \& J. Watson (Eds.), Creating a Caring Science curriculum: An emancipatory pedagogy for nursing (pp. 157-184). New York, NY: Springer Publishing Company. 
Buber, M. (1996). I and thou: A new translation, with a prologue and notes by Walter Kaufmann. (W. Kaufmann, Trans.). New York, NY: Touchstone. (Original work published 1970)

Cara, C. (2017, June). Rediscovering love, compassion, and caring to alleviate debumanization. Keynote speech presented at the 38th International Association for Human Caring Conference, Edmonton, AB, Canada.

Cara, C., Gauvin-Lepage, J., Lefebvre, H., Létourneau, D., Alderson, M., Larue, C., ... Mathieu, C. (2016). Le Modèle humaniste des soins infirmiers-UdeM: Perspective novatrice et pragmatique. Recherche en soins infirmiers, 125, 20-31. doi:10.3917/rsi.125.0020

Cara, C., \& Hills, M. (2018, May). The added value of Caring Science: Its contributions to bumanize nursing education. Oral presentation at the Canadian Association of Schools in Nursing Conference, Montreal, QC, Canada.

Chan, Z. C., Tong, C. W., \& Henderson, S. (2017). Power dynamics in the studentteacher relationship in clinical settings. Nurse Education Today, 49, 174-179. doi:10.1016/j.nedt.2016.11.026

Christoff, K. (2014). Dehumanization in organizational settings: Some scientific and ethical consideration. Frontiers in Human Neuroscience, 8(748), 1-5. doi:10.3389/ fnhum.2014.00748

Duchscher, J. E. B. (2001). Out in the real world: Newly graduated nurses in acutecare speak out. Fournal of Nursing Administration, 31, 426-439. Retrieved from http://journals.lww.com/jonajournal/Pages/default.aspx

Froneman, K., Du Plessis, E., \& Koen, M. P. (2016). Effective educator-student relationships in nursing education to strengthen nursing students' resilience. Curationis, 39(1), 1595. doi:10.4102/curationis.v39i1.1595

Gillespie, M. (2005). Student-teacher connection: A place of possibility. Fournal of Advanced Nursing, 52(2), 211-219. doi:10.1111/j.1365-2648.2005.03581.x

Halldorsdottir, S. (1990). The essential structure of a caring and uncaring encounter with a teacher: The perspective of the nursing student. In M. Leininger \& J. Watson (Eds.), The caring imperative in nursing education (pp. 95-108). New York, NY: National League for Nursing Press.

Halldorsdottir, S. (1991). Five basic modes of being with another. In D. A. Gaut \& M. Leininger (Eds.), Caring: The compassionate (pp. 37-49). New York, NY: National League for Nursing Press.

Halldorsdottir, S. (2013). Five basic modes of being with another. In M. C. Smith, M. C. Turkel, \& Z. R. Wolf (Eds.), Caring in nursing classics. An essential resource (pp. 201-210). New York, NY: Springer Publishing Company.

Haslam, N. (2006). Dehumanization: An integrative review. Personality and Social Psychology Review, 10(3), 252-264. doi:10.1207/s15327957pspr1003_4

Hills, M., \& Cara, C. (2019). Curriculum development processes and pedagogical practices for advancing Caring Science literacy. In W. Rosa, S. Horton-Deutsch, \& J. Watson (Eds.), A bandbook for Caring Science: Expanding the paradigm (pp. 197-210). New York, NY: Springer Publishing Company. 
Hills, M., \& Watson, J. (2011). Creating a Caring Science curriculum: An emancipatory pedagogy for nursing. New York, NY: Springer Publishing Company.

Labrague, L. J., McEnroe-Petitte, D. M., Papathanasiou, I. V., Edet, O. B., \& Arulappan, J. (2015). Impact of instructors' caring on students' perceptions of their own caring behaviors: Students' caring. Fournal of Nursing Scholarship, 47(4), 338-346. doi:10.1111/jnu.12139

Létourneau, D., Cara, C., \& Goudreau, J. (2017). Humanizing nursing care: An analysis of caring theories through the lens of humanism. International fournal for Human Caring, 21(1), 32-40. doi:10.20467/1091-5710-21.1.32

Létourneau, D., Goudreau, J., \& Cara, C. (2018, May). The experience of learning to care for the person with humanism: A phenomenological study. Communication presented at the 39th Annual International Association for Human Caring Conference, Minneapolis, $M N$.

Mayeroff, M. (1990). On caring. New York, NY: Harper Perennial. (Original work published 1971)

Miller, B. K., Haber,J., \& Byrne, N.W. (1990). The experience of caring in the teaching process of nursing education: Student and teacher perspectives. In M. M. Leininger \& J. Watson (Eds.), The caring imperative in education (pp. 255-266). New York, NY: National League for Nursing Press.

Muliira, J. K., Natarajan, J., \& van der Colff, J. (2017). Nursing faculty academic incivility: Perceptions of nursing students and faculty. BMC Medical Education, 17(1), 1-10. doi:10.1186/s12909-017-1096-8

National League for Nursing. (1988). Curriculum revolution: Mandate for change. New York, NY: National League for Nursing Press.

National League for Nursing. (2003). Position statement. Innovation in nursing education: A call to reform. Retrieved from http://www.nln.org/docs/default-source/ about/archived-position-statements/innovation-in-nursing-education-a-call -to-reform-pdf.pdf

Noddings, N. (2013). Caring. A relational approach to ethics and moral education. Berkeley: University of California Press.

Reason, P. (Ed.). (1994). Participation in human inquiry. London, UK: Sage.

Roach, M. S. (1984). Caring: The buman mode of being, implications for nursing. Toronto, ON, Canada: University of Toronto.

Roach, M. S. (2002). Caring, the buman mode of being: A blueprint for the bealth professions (2nd ed.). Ottawa, ON, Canada: Cambridge Health Alliance Press.

Roberts, S. J., \& Glod, C. (2013). Faculty roles: Dilemmas for the future of nursing education. Nursing Forum, 48, 99-105. doi:10.1111/nuf.12018

Rogers, C. R. (1961). On becoming a person: A therapist's view of psychotherapy. Boston, MA: Houghton Mifflin Company.

Seibel, L. M., \& Fehr, F. C. (2018). "They can crush you": Nursing students' experiences of bullying and the role of faculty. Fournal of Nursing Education and Practice, 8(6), 66-76. doi:10.5430/jnep.v8n6p66 
Smith, Y. M., \& Crowe, A. R. (2017). Nurse educator perceptions of the importance of relationship in online teaching and learning. Fournal of Professional Nursing, 33(1), 11-19. doi:10.1016/j.profnurs.2016.06.004

Stagg, S. J., Sheridan, D. J., Jones, R. A., \& Speroni, K. G. (2013). Workplace bullying: The effectiveness of a workplace program. A systematic review. Workplace Health and Safety, 61(8), 333-338. doi:10.1177/216507991306100803

Thomas, C.M. (2010). Teaching nursing students and newly registered nurses strategies to deal with violent behaviors in the professional practice environment. Fournal of Continuing Education in Nursing, 41(7), 299-310. doi:10.3928/00220124-20100401-09

Watson, J. (1988). Nursing: Human science and buman care (2nd ed.). New York, NY: National League for Nursing. (Original work published 1985)

Watson, J. (2008). Nursing: The philosophy and science of caring (revised ed.). Boulder: University Press of Colorado.

Watson, J. (2012). Human Caring Science: A theory of nursing (2nd ed.). Sudbury, MA: Jones \& Bartlett Learning.

Whealan, J. (2017). The Caring Science imperative: A hallmark in nursing education. In S. Lee, P. Palmieri, \& J. Watson (Eds.), Global advances in Human Caring literacy (pp. 33-42). New York, NY: Springer Publishing Company.

Zander, R. S., \& Zander, B. (2002). The art of possibility. New York, NY: Penguin Group.

Ziefle, K. (2018). Incivility in nursing education: Generational differences. Teaching and Learning in Nursing, 13(1), 27-30. doi:10.1016/j.teln.2017.09.004 